\title{
Chemical composition and calculated nutritive value of commonly available feedstuffs for ruminants in Burundi
}

\author{
P Pozy 1, D Dehareng 2, AG Deswysen 3 \\ 'Institut des Sciences Agronomiques du Burundi, BP 795, Bujumbura ; ${ }^{2}$ Faculté des Sciences Agronomiques, \\ Département des Productions Animales, Université du Burundi, BP 2940, Bujumbura, Burundi ; \\ 3Faculté des Sciences Agronomiques, Unité GENA, Université Catholique de Louvain, \\ Place Croix du Sud 2 (Boite 14), 1348 Louvain-la-Neuve, Belgique
}

Burundese domestic ruminants usually consume overday grasses from limited natural grasslands and rest overnight in stabulation. Their productions may be partially improved by supplementary feeding during stabulation. However, nutritive value of available feedstuffs used in small farms are not well known, leading to present work.

Samples of natural grass (feedstuff 1 ), cultivated grasses $(2$ to 5$)$ or legumes $(7,8)$, grass silage (6) and agro-industrial residues ( 9 to 15) were chemically analyzed, using classical procedures for dry matter (DM), crude protein (CP), fat, ash, $\mathrm{Ca}, \mathrm{P}$, and Kurschner's method for crude fibre (CF). Net energy (UFL, UFV) and intestinal digestible protein (PDIN, PDIE) content were calculated according to Demarquilly et al $(1978$, in : Alimentation des ruminants, INRA ed, Versailles, 469-584) and
Xandé et al (1989, in : Pâturages et alimentation des ruminants en zone tropicale humide, INRA ed, Paris, 21-30).

Chemical composition of feedstuffs 2 to 5,8 to 15 and nutritive value of feedstuffs 3,9 to 12 and 15 were similar to those reported respectively by Rivière (1991, in : Alimentation des ruminants domestiques en milieu tropical, IEMVT ed, Maisons-Alfort, 437-508) and Demarquilly et al (1978). PDIE-value of all analyzed grasses was higher than PDIN-value, as reported by Xandé et al (1989). Overall, nutritive value of Setaria $s p$, the best grass, is similar to the proposed tropical reference forage (Xande et al, 1989), however with a lower daily voluntary intake (57 versus $71 \mathrm{~g}$ $\mathrm{DM} / \mathrm{kg}$ BW $\left.{ }^{0.75}\right)$. These preliminary results already allow to propose Setaria $s p$ as the Burundese reference forage.

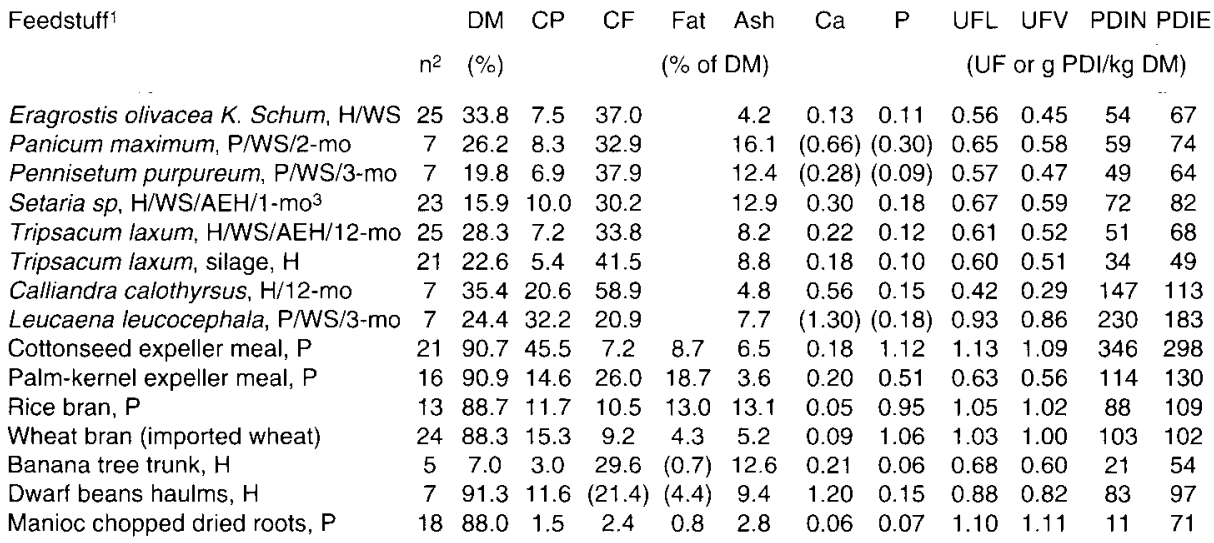

1 Samples collected : in highlands $(\mathrm{H})$, in plain (P)/during the wet season (WS)/from anti-erosive hedges (AEH)/after 1-, 2-, 3- or 12-mo (month) regrowth. 2 Number of samples analyzed. 3 Daily voluntary intake of $25-\mathrm{kg}$ local sheep $=57 \mathrm{~g} \mathrm{DM} / \mathrm{kg}$ BW $0.75 ;$ organic matter digestibility $=66 \% ;$ metabolizable energy $=2,004$ Mcal/kg DM (Deswysen et al, 1995 : in present Symposium). Data in brackets are from Rivière (1991). 